\title{
THE YOUNGEST STAGE IN THE EVOLUTION OF THE DINARIC CARBONATE PLATFORM: THE UPPER NUMMULITIC LIMESTONES IN THE NORTH DALMATIAN FORELAND, MIDDLE EOCENE, CROATIA
}

\section{Ljubomir Babić \& Jožica Zupanič}

\author{
Rokov perivoj 5, 10000 Zagreb, Croatia (e-mail: ljubbabic@gmail.com)
}

Babić, Lj. \& Zupanič, J.: The youngest stage in the evolution of the Dinaric carbonate platform: the Upper Nummulitic Limestones in the North Dalmatian foreland, Middle Eocene, Croatia. Nat. Croat., Vol. 25, No. 1., 55-71, 2016, Zagreb.

The paper provides a description of the poorly known Upper Nummulitic Limestones exposed in the North Dalmatian foreland basin of the Outer Dinarides in Croatia. This formation originated on a land-attached ramp-type platform with a temperate sediment production. It transgressively overlies older platform limestones and includes limestones deposited in very shallow, restricted settings, which subsequently evolved into carbonate platform environments typified by diversified biota. The succession terminated at a drowning unconformity, which is intra-Bartonian (Middle Eocene) in age based on biostratigraphic interpretations of the larger foraminifera present. This study demonstrates that the history of the carbonate platform of the Outer Dinarides extends into the Bartonian and that the studied limestones document the youngest, hitherto unknown stage in the platform development. The SW margin of the Upper Nummulitic platform was dissected by faults and prone to collapse, which represented the source for megabreccias deposited in an adjacent basin. This platform-basin system represents a new element in the sedimentary and tectonic evolution of the Dinaric foreland.

Key words: carbonate platform, drowning unconformity, foreland basin, megabreccias, Eocene, Outer Dinarides

Babić, Lj. \& Zupanič, J.: Najmlađi stadij u razvitku Dinarske karbonatne platforme: Gornji Numulitni Vapnenci u predgornom bazenu sjeverne Dalmacije, srednji Eocen, Hrvatska. Nat. Croat., Vol. 25, No. 1., 55-71, 2016, Zagreb.

Ovaj prilog dobavlja opis slabo poznatih Gornjih Numulitnih Vapnenaca iz sjeverno-dalmatinskog predgornog bazena Vanjskih Dinarida Hrvatske. Ta formacija nastala je na platformi tipa rampe, koja je pripadala umjerenoj sedimentacijskoj provinciji. Ona transgresivno naliježe na starije platformske vapnence i početno uključuje vapnence taložene u vrlo plitkim, ograničenim uvjetima, a zatim vapnence s diverzificiranom biotom. Slijed se svršava tonjenjem (tzv. drowning unconformity), koje se dogodilo unutar Bartonija na što upućuje biostratigrafija nađenih velikih foraminifera. Ova studija pokazuje da se povijest karbonatne platforme Vanjskih Dinarida proteže i u Bartonij, te da proučeni vapnenci dokumentiraju najmlađi, dosad nepoznati stadij u razvitku platforme. Jugozapadni rub Gornjo-numulitne platform bio je zasječen rasjedima i sklon kolabiranju te je pretstavljao izvor za megabreče taložene u susjednom bazenu. Taj sustav platforma-bazen pretstavlja novi element za razmatranje taložnog i tektonskog razvitka Dinarskoga predgorja.

Ključne riječi: karbonatna platforma, tonjenje, predgorni bazen, megabreče, Eocen, Vanjski Dinaridi

\section{INTRODUCTION}

The outer, SW part of the Dinaric Mountain chain, usually called the Outer Dinarides, predominantly consists of shallow-marine carbonates deposited during the prolongedLate Triassic, Jurassic, Cretaceous and Palaeogene time periods. The character of these 
carbonate deposits reflects the evolution of one of the broadest and thickest carbonate platforms of the Mediterranean realm. The varied facies, their regional distribution, individual sedimentary units and stratigraphic gaps, as well as details on successive palaeogeographic reconstructions and the influence of tectonics on the sedimentary evolution have already been described in numerous publications (reviews in VlaHović et al., 2005 with references; Korbar, 2009 with references). During its Mesozoic to Palaeogene evolution the carbonate platform experienced a successive reduction in size best known along its NE margin (reviews in Aubouin et al., 1970; Dragičević \& Velić, 2002 with references). The platform underwent important changes towards the end of the Cretaceous related to an increased influence of tectonic deformation (see discussion in VLAhović et al., 2005); however shallow-marine carbonates were still deposited in the Palaeogene when platform conditions characterized what is now a wide, long belt along the Adriatic coast and hinterland. Relevant deposits are mainly represented by well known Foraminiferal Limestones of Palaeocene to Middle Lutetian age. These limestones have generally been regarded to represent the last platform carbonates which are finally overlain by clastics derived from the orogen located NE. The present paper deals with platform carbonates which overly the Foraminiferal Limestones and reflect a subsequent stage of the carbonate platform history not recognized previously. They are exposed in the North Dalmatian foreland basin of the Outer Dinarides and have already been identified as a separate stratigraphic unit and named the Upper Nummulitic Limestones more than 100 years ago (SCHubert, 1904, 1905, 1908, 1909). However, their features and their role in the basin evolution remained poorly known. Even though their main extent was mapped by SCHUBERT as early as 1909, these strata were not included in a later geological map of the area, nor noted in the explanatory notes by Ivanović et al. $(1973,1976)$. They have been reported only as „detrital limestones" and „fossiliferous limestones" by Muldini-Mamužić (1972) and Majcen \& Korolija (1973), when dealing with the area to the NW of the map presented by SchUbert (1909).The present contribution describes the characteristics of the Upper Nummulitic Limestones. Special attention was paid to the top of the platform succession marked by a significant change in facies. This was used to define the character and position of an important stratigraphic boundary which is intra-Bartonian in age based on new biostratigraphic data. Furthermore, there was a need to describe the relationship with the underlying and overlying sedimentary units, as well as correlative deposits both parallel and perpendicular to the NW-SE basin elongation. This served to explain the position of the described carbonate platform succession and related units within the evolution and stratigraphy of the NW part of the foreland basin.

\section{GEOLOGICAL SETTING}

The examined strata are located within the Palaeogene North Dalmatian foreland basin of the Outer Dinarides (Fig. 1). The basin is situated within an imbricate-folded belt bounded on both sides by major thrusts (Fig. 1b). The belt mainly consists of Cretaceous to Eocene platform carbonates that overlay heterogeneous, mainly clastic, Palaeogene deposits, which formed in a variety of depositional settings, including deep water, shelf, beach, deltaic and alluvial. It has been proposed that the upper part of the Palaeogene succession, i.e. the Promina Beds of Schubert (1904, 1908, 1909) (Fig. 2, 3), was deposited in a basin carried piggyback on a large, complex nappe (Korbar, 2009; MrINJEK et al., 2012). The area also contains minor Neogene and Quaternary deposits. 


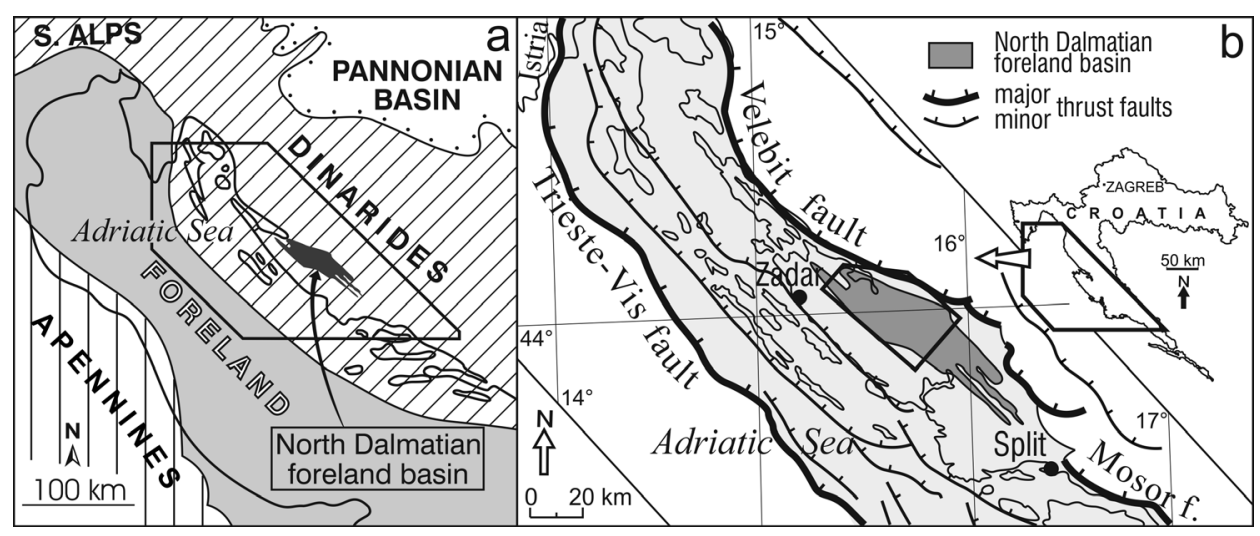

Fig. 1. Overall situation of the study area. a, Location of the North Dalmatian foreland basin in the outer part of the Dinaric orogeny in Croatia. Framed area is shown in Fig. 1.b. b, Location of the foreland basin (dark grey) within the imbricate-folded belt (light grey) which is bound by major thrust faults. Structural features are simplified after Prelogović et al. (2003, with references). Framed area is shown in Fig. 2.

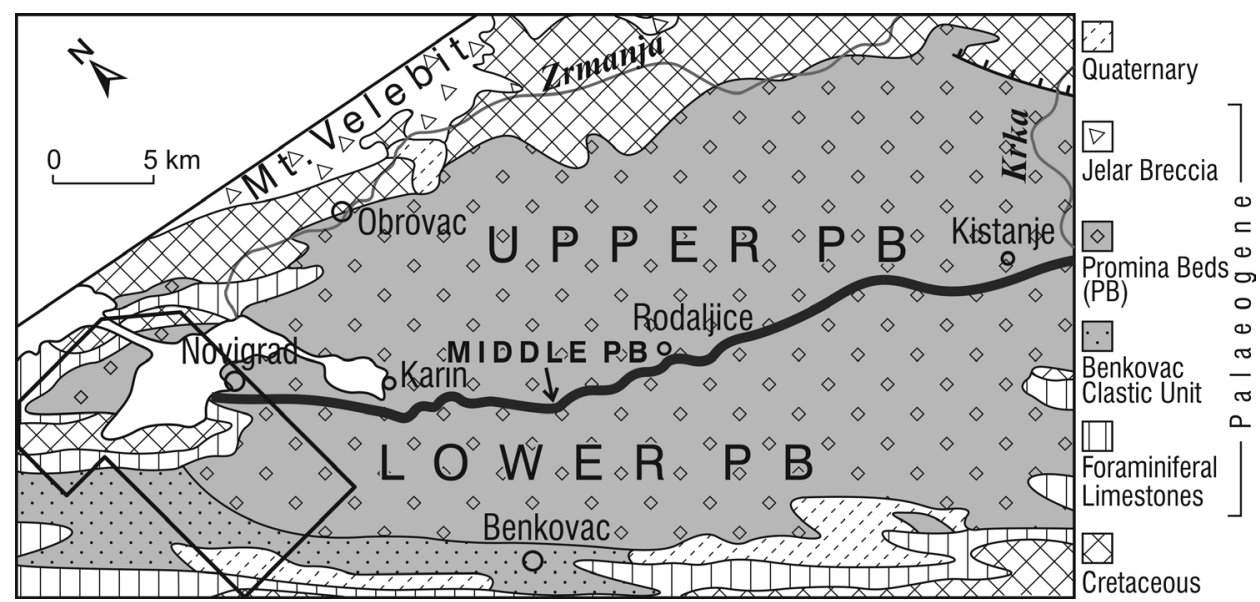

Fig. 2. NW and central parts of the N Dalmatian foreland basin (in grey) with surroundings. Partly simplified after SAVEZni GeološKi ZAVod (1970). Three parts of the Promina Beds after Babić \& Zupanič (2012). Framed area is shown in Fig. 3A.

The formation of the North Dalmatian Foreland Basin was related to the propagation of tectonic deformation of the Dinaric orogen towards the SW and related impact of imposed tectonic load. The early evolution of the basin may be regarded to have begun with the rise of a forebulge which induced the subaerial exposure of Upper Cretaceous platform carbonates. This was followed by a transgression and the deposition of an upward-deepening carbonate ramp succession of Foraminiferal Limestones (Fig. 3B) (Drobne et al., 1991; Babić \& Zupanič, 2008; Babić et al., 2010) which is $220 \mathrm{~m}$ thick (IvANović et al., 1976). The ramp succession is Middle Cuisian to earliest late Lutetian in age 
(Drobne et al., 1991; Fig. 3) including the topmost "transitional limestones", which together with overlying marls reflect the inability of carbonate production to keep pace

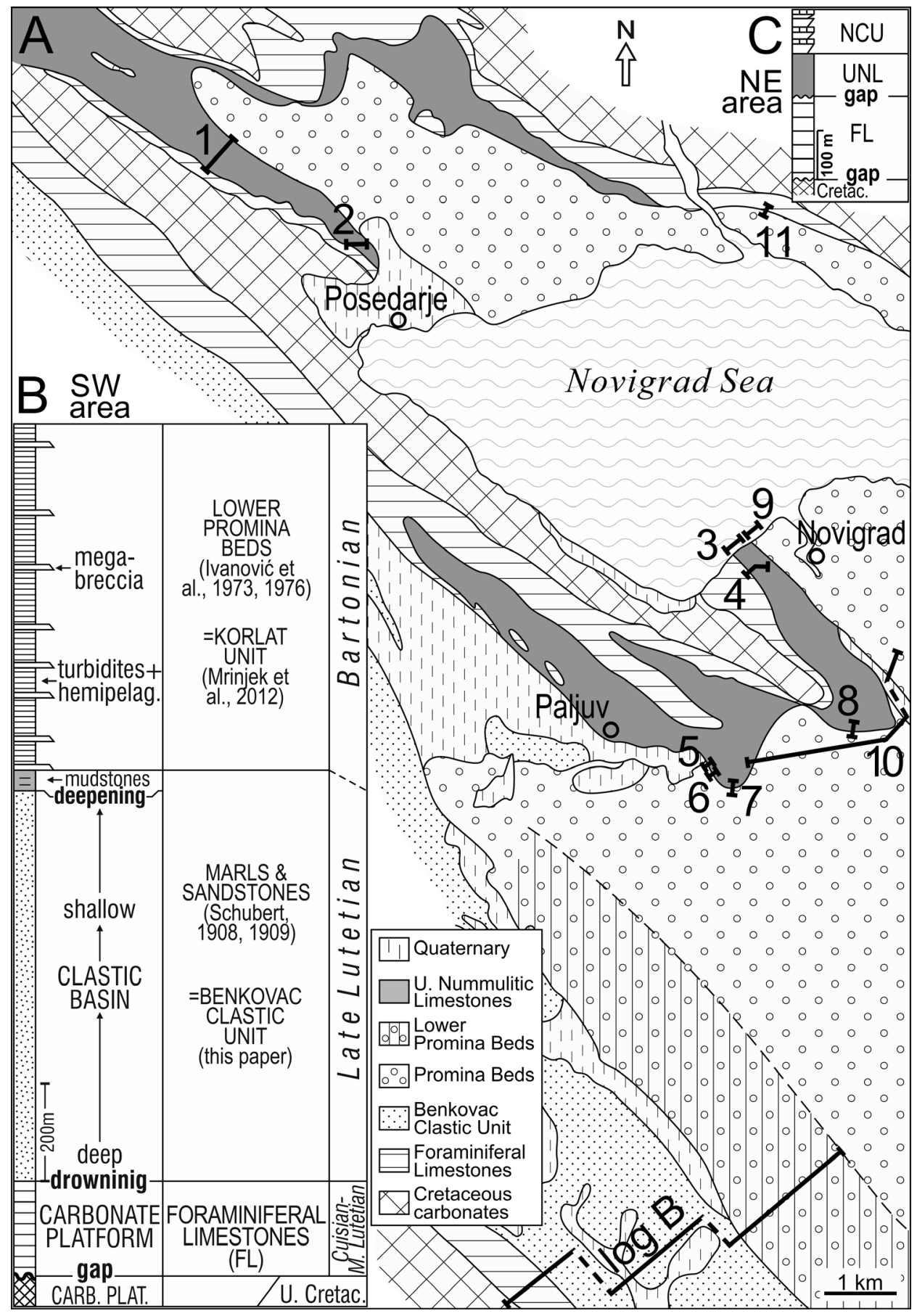


with subsidence (Schubert, 1905; Ivanović et al., 1976; Drobne et al., 1991; Babić \& ZuPANIČ, 2008). The following Benkovac Clastic Unit (new name) is a turbiditic to delta-front succession (BAbić \& Zupanič, 2008) of Late Lutetian age (Schubert, 1905; Ivanović et al., 1976) overlain by offshore mudstones (Fig. 3B).The succession of ramp limestones, hemipelagites and turbidites corresponds to SINCLAIR's (1997) „underfilled trinity“ model of foreland basin evolution. The Benkovac clastics are overlain by the Promina Beds of Schubert $(1908,1909)$. After Mrinjek et al. (2012) and Pencinger (2012) the Promina Beds have been deposited in small sub-basins originated by the formation of a series of blindthrust growth folds within the Promina piggyback basin. The lower part of the Promina Beds (here: Lower Promina Beds) has been delineated by Ivanović et al. $(1973,1976)$ and later called Korlat Unit (MrinjeK et al., 2012). It started in Bartonian (BENIć, 1975) and consists of turbidites and hemipelagites, as well as outstanding carbonate megabreccias (Zupanič \& Babić, 1980/81; Babić \& Zupanič, 1983) (Fig. 3B). A detailed, amply illustrated description of the unit has been provided by Mrinjek et al. (2012) and Pencinger (2012). The overlying deposits are out of the scope of this paper and include turbidites, tempestites, alluvial deposits, rare shallow-marine limestones and coastal clastics. Relevant information about these strata can be found in Zupanič \& BABIĆ (2011), BABić \& Zupanič (2012), Mrinjek et al. (2012) and Pencinger (2012), and references therein.

Unlike the succession of the SW part of the basin shortly reviewed above, which is widely known as typical for the coastal Dinarides and hinterland, the NE part of the basin displays a different Palaeogene succession. The Foraminiferal Limestones (FL) in this area end at a karstified surface with local bauxites (SAKAČ, 1961; IvAnović et al., 1973). The surface is overlain by the Upper Nummulitic Limestones (UNL) of SCHUbERT (1908, 1909) (Fig. 3C), details of which are the main topic of the present study and are described below. The same area also contains a younger, Novigrad Cyclic Unit (NCU) which consists of alternating clastic shelf-to-beach segments and limestone segments, and terminates with a condensed horizon („Middle Promina Beds“ of Babić \& Zupanič, 2012). During the Palaeogene there were several tectonic pulses (e.g. ZupANič \& BABIć, 2011; MrinJeK et al., 2012) however, the most important deformation involving the entire North Dalmatian foreland basin occurred in Oligocene-Miocene (SCHUBERT, 1905, 1909).

\section{STUDY AREA AND METHODS}

The study area corresponds to the NW part of the North Dalmatian foreland basin (Figs. 2, 3A). Field work included the study of facies, logging and tracing combined with mapping. The geological map of SCHUbERT (1909; Fig. 3A) facilitated a search forappropriate exposures, especially near the top of the unit. Depositional facies were examined in about 120 petrographic thin-sections, which were also used for age determination by means of larger foraminifera. It must be mentioned that landmines from the Croatian War of Independence are still present in smaller, isolated parts of the study area.

\section{$\Leftarrow$}

Fig. 3. Geology of the study area. A, Geological map of the NW part of the foreland basin (partly simplified after Schubert, 1909). 1 to 11, Studied sections. B, Simplified succession of the outer part of the basin. C, Simplified succession of the inner part of the basin (FL, Foraminiferal Limestones; UNL, Upper Nummulitic Limestones; NCU, Novigrad Cyclic Unit). For details including age dating in B, see text and other figures. Note that the Lower Promina Beds of Ivanović et al. $(1973,1976)$ are not identical to the Lower Promina Beds in Fig. 2. 


\section{SEDIMENTARY UNITS}

\section{Deposits underlying the Upper Nummulitic Limestones: Foraminiferal Limestones (FL)}

The FL in the study area are largely similar to the shallow marine FL of the outer, SW part of the basin described by DROBNE et al. (1991), however here their upper part is missing. Also lacking are the transitional facies and overlying deep-water clastics typical of the outer area, and the top of the FL is here characterized by a karstification surface (Figs. 3B, 3C, 4). Bignot (1975) reported Lutetian age of the limestones based on larger foraminifera; however more recent interpretations (e.g. SERRA-KIEL et al., 1998) indicate Ypresian and Early Lutetian age. Consequently, the youngest part of the FL is here older than in the SW area.

\section{Upper Nummulitic Limestones (UNL)}

\section{Description}

The UNL was identified, mapped and named by Schubert (1908, 1909) (Fig.3A). Parts of its extent have also been mapped later (SAKAČ, 1961; MAJCEN et al., 1973). The UNL overlies the karstified top of the FL. Their thickness of about $90 \mathrm{~m}$ (BABIĆ \& ZupANič, 2012) refers to section 3 in Fig. 3A, whose lower-middle part displays a few faults. Sections 2, 3 and 4 (Figs. 3A, 4) do not have the highest part of the unit nor the transition into the overlying deposits, both of which were examined in sections 1, 5 to 8 and 10 (Figs. $3 \mathrm{~A}, 4)$. The actual thickness of the unit may therefore be estimated at about 60 to $90 \mathrm{~m}$.

The UNL starts with thin conglomerates containing clasts of the FL and Upper Cretaceous limestones. Limestones of the lower part of the unit include wackestones to packstones (Plate I, Fig. 1) containing common miliolids, Orbitolites, smaller benthic foraminifera, locally abundant echinoids, and rare solitary corals. The middle part of the unit (Plate I, Figs. 2-4) is represented by poorly bedded grainstones, packstones and boundstones, as well as rare wackestones and very rare mudstones. Locally observed are small coral heads and bushes and small patch reefs or mounds consisting of corals encrusted by corallinaceans and/or attached foraminifera, and internal filling of variously textured sediments. Skeletal particles are varied smaller and larger benthic foraminifera, corallinaceans (branches and encrustations), encrusting acervulinids and other attached foraminifera, agglutinated foraminifera, echinoid calcite grains and spines, bryozoans, corals, gastropods, bivalves, worms and holothurian sclerites. There are examples of massive occurrence of corallinaceans and/or encrusting acervulinids. Acervulinids commonly display circular and semicircular, ring-like shapes. Also present are rhodoliths. A small-scale cyclicity seems to be present, but has not been studied further.

The upper part of the UNL (Fig. 4) includes packstones and wackestones which besides the constituents mentioned above, may also contain planktonic foraminifera. Discocyclina becomes more common, while Orbitolites disappears. Towards the top, wackestones become dominant and mudstones are also present, both of which are characterized by organically bored skeletal debris (Plate I, Fig. 5), Fe-mineralized skeletal fragments, as well as glauconite which is present within skeletons and rarely as isolated grains. In addition, a hardground represented by a sharp, irregular, intensely bioturbated surface has been observed close to the top of the unit (section 7 in Fig. 3).

Middle and upper parts of the UNL contain a variety of larger foraminifera: Orbitolites, Fabiania, Asterigerina, Discocyclina, Nummulites, Asterocyclina, Actinocyclina, Amphi- 


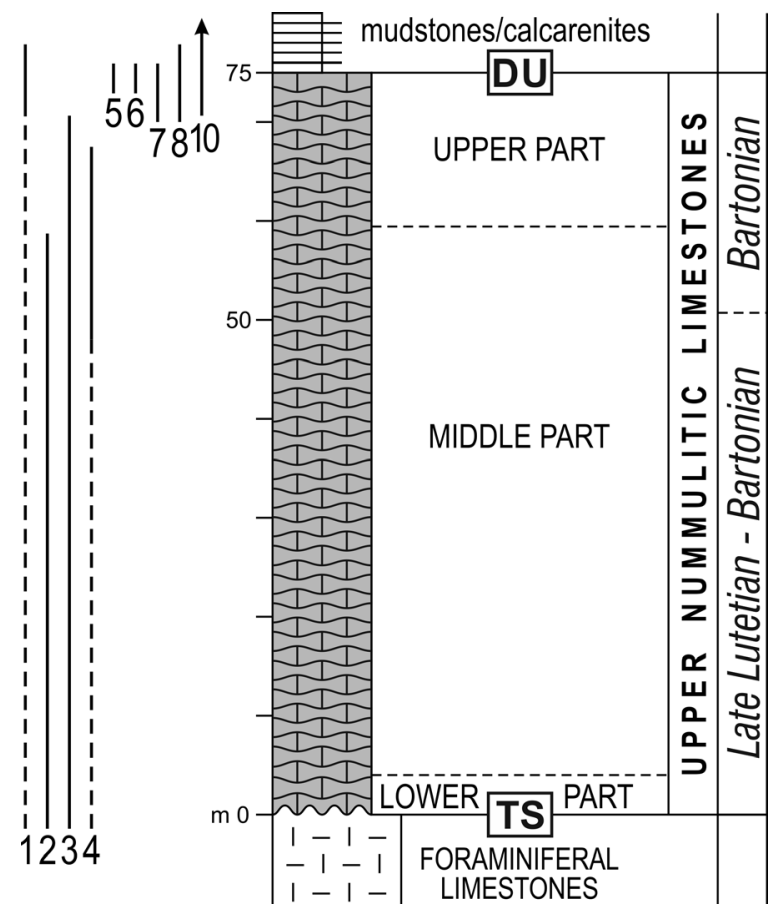

Fig. 4. Synthetic log of the Upper Nummulitic Limestones. Lines 1 to 8 and 10 refer to sections (see Fig 3A) used to construct the log (dashed portions of the lines = partly exposed intervals). Underlying the UNL are platform carbonates of the Foraminiferal Limestones; overlying are deposits of the deeper marine settings. TS, Transgressive surface. DU, Drowning unconformity. For details see text.

stegina, Operculina, Heterostegina, Sphaerogypsina, Halkyardia minima (LiEBus) (Plate II, Fig. 1), Linderina (Plate II, Fig. 3), Rotalia and Orbitoclypeus. Higher in the middle part, as well as in the upper part there are Eoannularia eocenica Cole \& Bermudez, Borelis vonderschmitti (Schweighauser), Glomalveolina ungaroi Bassi \& Broglio Loriga, Silvestriella tetraedra (GümbeL) and Biplanispira (Plate II).

\section{Age of the UNL}

The association of H. minima (Late Lutetian-Early Oligocene), Linderina (LutetianBartonian), and Orbitolites (ending in Bartonian) (ages after SERrA-Kiel et al., 1998; BouDAGHER-FADEL, 2008) indicates a Late Lutetian to Bartonian age for the UNL. E. eocenica (Late Bartonian-Priabonian: Özcan et al., 2009; Middle Eocene: BoudAgher-FAdel, 2008), Biplanispira (Late Bartonian-Priabonian: SERRA-KIEL et al., 1998; Lutetian-Priabonian: BoUDAGHER-FADEL, 2008), B. vonderschmitti and G. ungaroi (Late Bartonian-Priabonian: Serra-Kiel et al., 1998; Bassi \& Loriga Broglio, 1999) and S. tetraedra (Bartonian: SerraKiel et al., 1998) taken together indicate a Bartonian age. These data suggest that the UNL as a whole is either Late Lutetian and Bartonian, or possibly, entirely Bartonian in age (Fig. 4).

There are difficulties concerning the use of previous age interpretations, which were based on former views on taxonomy and biostratigraphy. SCHUBERT $(1904,1905)$ first 
suggested a Late Eocene age, and later, a probable late Middle Eocene age of the unit (SCHUBERT, 1909), while the fossils which he cited seemingly correspond to the Bartonian of the modern stratigraphic scale. Muldini-Mamužić (1972) and Ivanović et al. (1976) cite a Late Eocene age based on Nummulites and Discocyclina species, and Globigerina corpulenta. The cited larger foraminifera possibly correspond to those occurring in the

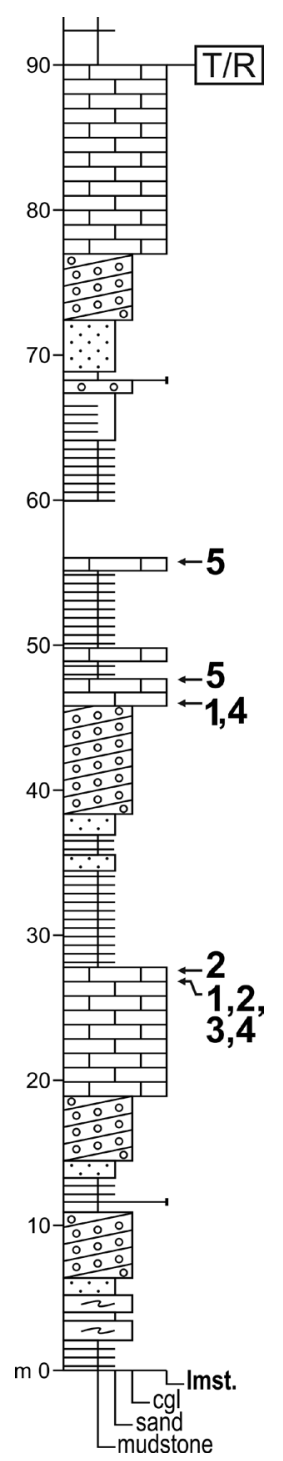

Fig. 5. Log of the NCU (=Middle Promina Beds) from section 9 in Fig. 3A (simplified after BABIĆ \& ZuPANIČ, 2012) with location of larger foraminifera most relevant for age determination: 1, Eoannularia eocenica; 2, Borelis vonderschmitti; 3, Glomalveolina ungaroi; 4, Halkyardia minima; 5, Silvestriella tetraedra. The basal part of NCU is covered. T/R, transgressive-regressive turnaround surface marked by a condensed horizon. 
Bartonian and some of them, in the Priabonian (SErra-Kiel et al., 1998), while G. corpulenta (according to the present-day understanding of this species) already occurs in the Bartonian (Toumarkine \& Luterbacher, 1985). In addition, Muldini-Mamužić (1972) and Ivanović et al. (1976) regarded the Bartonian as a part of the Late Eocene in accordance with the stratigraphic classification of KRAŠENINNIKOV (1965) and this is reflected in their age determinations (see also KRAŠEnINNIKOv et al., 1968).

\section{Environmental conditions during the deposition of the UNL}

The onset of the UNL deposition resulted from a transgression over the emerged limestone basement composed of FL. Miliolid wackestones and packstones of the lower part of the unit indicate initially restricted marine conditions (bays, lagoons), while the diversified biota presents farther upsection suggests a well aerated, healthy carbonate platform. From time to time, small patch reefs, built by corals and encrusters, proliferated. The ring-like shapes of acervulinid foraminifera suggest their attachment to stems and branches of marine plants, i.e. their epiphytic behavior. This indicates the deposition in rather shallow parts of the photic zone and that seagrass meadows represented an important component of platform environments. Common and locally massive occurrence of corallinaceans explains why SCHUbert $(1904,1905,1909)$ sometimes used the alternative name Lithothamnium Limestones for the UNL. The character of the facies succession from initial flooding to the establishment of the platform suggests its ramp-type character, and that the transgression was advancing landwards, i.e. towards the NE.

The upper part of the unit, including the appearance of planktonic foraminifera, a hardground, the dominance of wackestones and mudstones, occurrence of Fe-mineralization and glauconite, reflects a lowering of sedimentation rate and a deepening trend. This was a consequence of the inability of the carbonate production to keep pace with relative sea-level rise. The contact between these limestones and the overlying mudstones deposited in deeper water (described below) represents a "drowning unconformity"(Schlager, 1989, 1991). In our case, the contact is Bartonian in age as documented above, which is additionally supported by age determination of the overlying unit, which is reported further in the text.

The absence of non-skeletal particles, minor mud component, an almost exclusive presence of skeletal sand, the dominance of fragmented skeletons, and predominantly calcite mineralogy are characteristic features of non-tropical carbonates as defined by Nelson (1988). In addition, the character of these deposits corresponds to a temperate sediment province of the „Heterozoan Association" as reviewed by JAmes (1997). These features typically characterize ramp-type platforms, as was the case of the Upper Nummulitic Limestones.

\section{Deposits overlying the UNL}

Sedimentary evolution following the UNL and the drowning unconformity varies along strike, i.e. parallel to basin elongation. The facies and thickness that typify the sedimentary succession to the NW are considerably different from the succession in the SE parts of the basin.

To the NW the sedimentary succession starts with mudstones containing smaller benthic and planktonic foraminifera (section 1, largely covered in sections 3 and 4; Figs. 3A, 4, 6a, 6b) and continues with a $90 \mathrm{~m}$ thick Novigrad Cyclic Unit (NCU) (section 9 in Figs. 3A, 5) described previously as the „Middle Promina Beds" (Babić \& Zupanič, 2012) (Fig. 2). The cycles consist of alternating coarsening-upward shelf to beach clastic segments, 


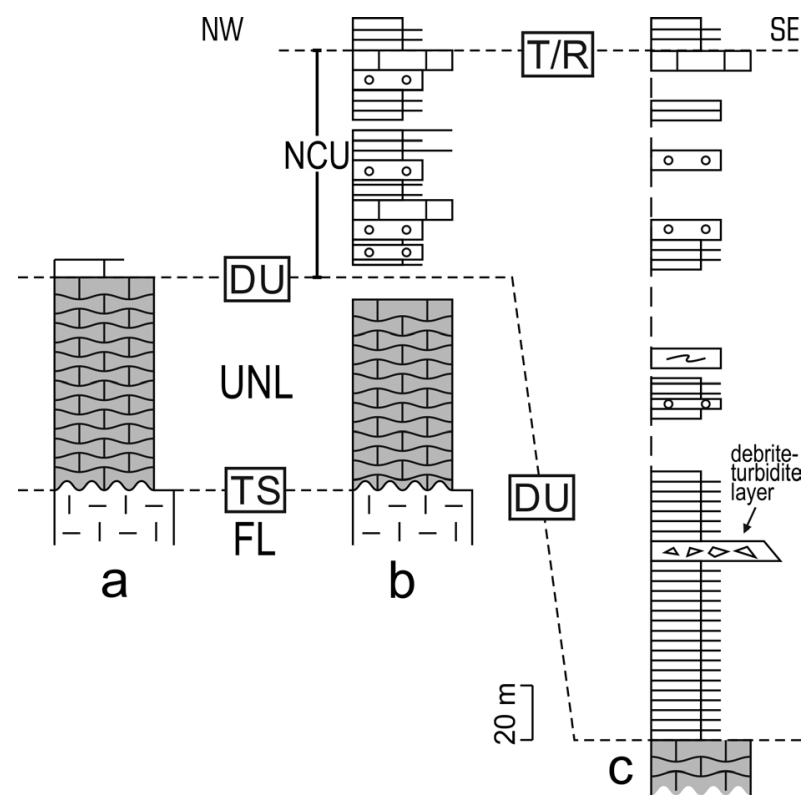

Fig. 6. Along strike (NW-SE) correlation of the Upper Nummulitic Limestones (in grey) and associated deposits. Log a represents sections 1 and 2 in Fig. 3A and 4. Log b includes sections 3 and 9 in Fig. 3A; the Novigrad Cyclic Unit (NCU) is also shown in Fig. 5. Log cis based on sections 5 to 8 and 10 in Fig. 3A and 4. The middle-upper part of section 10 is in a folded area and has not been studied in detail. TS, Transgressive surface. DU, Drowning unconformity. T/R, Transgressive-regressive turnaround surface. For explanation see text. Symbols for lithology as in Fig. 5 (bottom).

and shallow-marine limestone segments. The limestones are particularly important because they contain larger foraminifera used here for age determinations of the UNL. The limestones include wackestones, packstones and subordinate mudstones with smaller and larger foraminifera, corallinaceans, bivalves, gastropods, echinoids and corals. Among larger foraminifera there are Discocyclina, Asterigerina, Nummulites, Assilina, Orbitolites, Fabiania and Heterostegina, and also Eoannularia eocenica, Borelis vonderschmitti, Glomalveolina ungaroi, Halkyardia minima and Silvestriella tetraedra (Plate III). All of them have been also documented from the underlying UNL, and they indicate a Bartonian age of at least the lower half of the NCU (references cited above) and presumably of the entire unit (Fig. 5). The top of the NCU is marked by condensed limestones and a transition to overlying regressive deposits (BABIĆ \& Zupanič, 2012; T/R in Figs. 5 and 6).

The succession to the SE is represented by about $70 \mathrm{~m}$ thick alternation of lime mudstones and graded calcarenites (Fig. 6c; section 10 in Fig. 3A), both of which locally contain planktonic and smaller benthic foraminifera. Overlying is a $6 \mathrm{~m}$ thick debriteturbidite layer and more than $30 \mathrm{~m}$ thick deposits similar to those from the lower part of the succession. These deposits indicate a deeper marine setting created by drowning of the Upper Nummulitic carbonate platform. Overlying strata have not been studied in detail. According to our reconnaissance data, they consist of about $100 \mathrm{~m}$ (including covered intervals) of mudstones, calcarenites and conglomerates, which are in turn overlain by poorly exposed cycles of the NCU (Figs. 3C, 5, 6). 
Using two main bounding surfaces, i.e. the drowning unconformity below and the transgressive-regressive turnaround surface above, as well as the lateral extent of the UNL and the NCU, it can be concluded that a considerable part of the SE succession pinches out laterally in the NW direction (Fig. 6). As both of these bounding surfaces represent quasi-time lines, this lateral trend resulted from a considerable strike-parallel difference in subsidence rate during the time of deposition. Lateral differences in composition and thickness of sedimentary successions related to synsedimentary tectonic evolution have already been reported from several parts of the North Dalmatian foreland basin (Zupanič \& Babić, 2011; Babić \& Zupanič, 2012; Mrinjek et al., 2012; Pencinger, 2012), and will be in the focus of our future investigations.

\section{DISCUSSION}

\section{Position of the UNL within the basin: stratigraphy and palaeogeography along the NE-SW traverse}

The landward extent of the UNL is indicated by erosional remains of fossiliferous limestones located to the NE of the main outcrop area of the UNL, which includes a modest, only $3.5 \mathrm{~m}$ thick exposure of shallow-marine limestones (section 11, Fig. 3A, 7C). The limestones overlay the FL and local bauxite deposits, and terminate at an erosional surface covered by younger alluvial clastics (BABIć et al., 2010). This suggests that the transgression that resulted in the deposition of the UNL had spread even farther landward or towards the NE, in the direction the carbonate platform was attached to the land. The transversal width of the platform was greater than $11 \mathrm{~km}$ based on the presentday distribution of relevant outcrops, assuming a tectonic shortening ratio of 1.5 and a limited continuation of the UNL towards the SW.

Deeper marine environments adjacent to the platform are envisaged to have been present to the SW, which means that coeval deposits should be located within the continuous Palaeogene succession there (Fig. 3B). A good candidate appears to be the Lower Promina Beds (Ivanović et al., 1973, 1976) (= Korlat Unit of MrinjeK et al., 2012). Aside from classical turbidites deposited by longitudinal, NW-directed flows and minor mudstones, these strata contain intercalations of thick carbonate megabreccias derived from an adjacent carbonate platform. These megabreccias consist of a lower debris-flow division deposits including large limestone blocks (up to $200 \mathrm{~m}$ in diameter), boulders and smaller clasts, together with extra-sized intraclasts, varied macrofossils and larger foraminifera, and an upper turbidite division deposits containing common larger foraminifera (ZupANič \& BABIĆ, 1980/81; BABIĆ \& ZupAnič, 1983). Aside from blocks and other clasts of the FL there are also large blocks and smaller clasts of coral-corallinacean boundstones representing parts of former reefs and mounds, as well as large clasts of packstones and wackestones rich in corallinaceans and larger foraminifera, and individual, large coral heads (op. cit.). It has been suggested that the limestone clasts were mostly derived from a fault-bounded succession of different Eocene platform carbonates, while skeletal material came from shallow environments, both located to the NE (BABIć \& ZUPANIČ, 1983). In contrast, MrinjeK et al. (2012) and PENCINGER (2012) proposed a derivation of lithoclasts from a rising anticline on the outer, SW side of the basin. However, the facies of coral-corallinacean boundstones related to reefs and mounds, and thick packstones to wackestones rich in corallinaceans and larger foraminifera, are not known from the Palaeogene carbonates of the outer side of the basin, while similar facies occur within the UNLdescribed above. This suggests a sediment supply for the megabreccias from the 


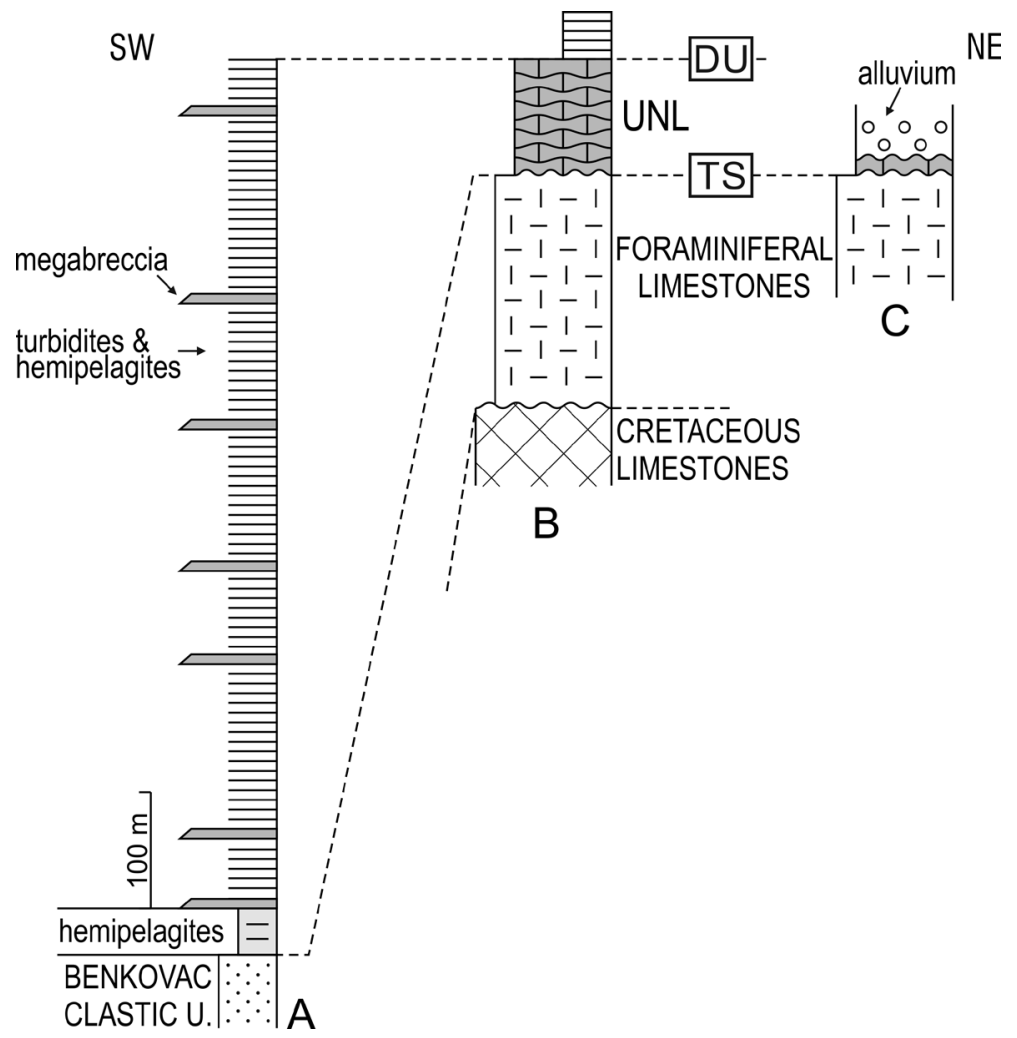

Fig. 7. Proposed correlation of the Lower Promina Beds of Ivanović et al. $(1973,1976)$ in log A (=upper part of $\log$ B in Fig. 3) and Upper Nummulitic Limestones (UNL) shown in logs B (sections 1-8 in Fig. 4) and C (section 11 in Fig. 3A). TS, Transgressive surface. DU, Drowning unconformity. For details see text.

inner, NE side of the basin, characterized by a succession of the FL and the overlying UNL. This relationship implies a genetic relation of the UNL and the Lower Promina Beds of Ivanović et al. (1973, 1976) (=Korlat Unit of MrinjeK et al., 2012) (Figs. 7, 8). Accor-

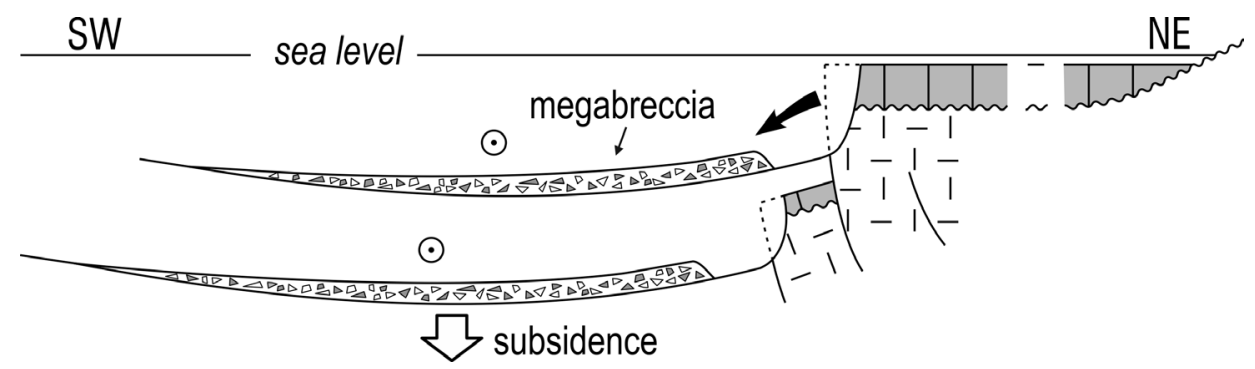

Fig. 8. Conceptual model relating depositional setting of the UNL (in grey) and the Lower Promina Beds of Ivanović et al. $(1973,1976)$. Megabreccias deriving from the SW platform margin alternate with calcarenites and mudstones showing a longitudinal, NW-directed palaeotransport (circles with central points). For further explanation see text. 
dingly, the same trend of relative sea-level rise may have been responsible for both the transgression that resulted in the UNL deposition to the NE, and in the deepening which enabled the deposition of offshore mudstones above shallow-marine sandstones in the SW area of the basin (Fig. 3B). This also implies a similar age of the UNL and the Lower Promina Beds of Ivanović et al. (1973). However, there may have been a delay in the first delivery of carbonate detritus to the basin, in which case the onset of the deposition of the Lower Promina Beds might be younger than the transgression associated with the UNL deposition. The delay may have been related to the storage of early delivered sediments in the proximal basin and relative sea-level rise leading to coeval sediment starvation offshore as a consequence of active tectonic loading (e.g. BLAIR \& BILOdEAU, 1988; Burns et al., 1997).

\section{Novigrad Cyclic Unit, the basin stratigraphy and short-lived carbonate platforms}

The NCU in the study area extends fortens of kilometers across the basin towards the SE where it separates the underlying (older) from the overlying (younger) Promina Beds
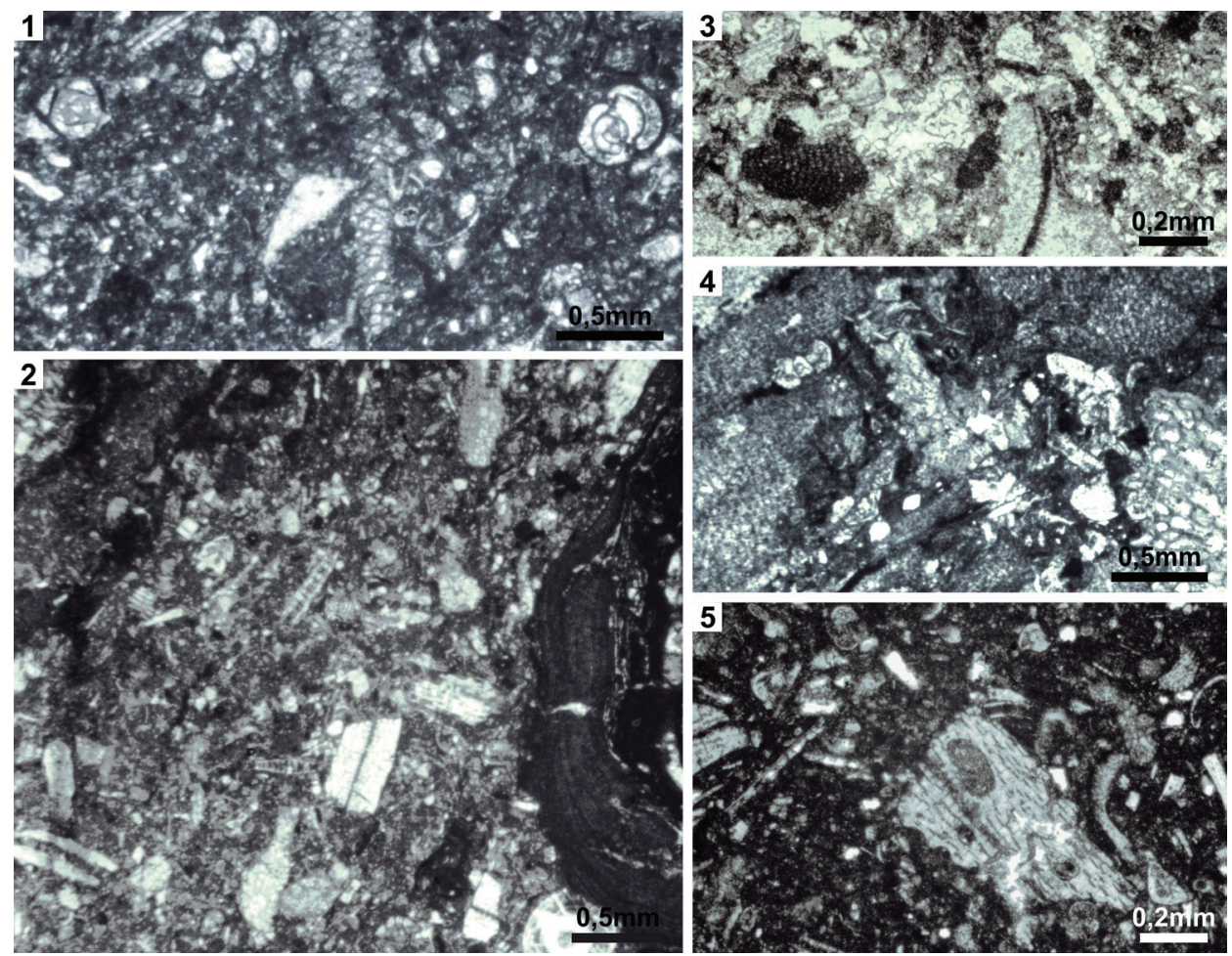

Plate I. Examples of microfacies from the Upper Nummulitic Limestones. 1, Skeletal packstone including miliolids and Orbitolites (center) from the lower UNL. 2, Skeletal packstone with a rhodolite (right). 3, Lime grainstone dominated by skeletal fragments; dark particles are corallinaceans; middle UNL. 4, Skeletal packstone including acervulinids and Fabiania (lower right); middle UNL. 5, Lime wackestone with fine to coarse skeletal debris including an organically bored fragment of Discocyclina (largest particle); upper UNL. 1 \& 4 from section 3; 2 from section 8; 3 from section 4; 5 from section 1. Location in Figs. 3 and 4. 
(Fig. 2). Consequently, also in that part of the basin the deposition of the older Promina Beds ended in the Bartonian, and the deposition of the Promina Beds younger than the NCU probably began already in the Bartonian. This is applicable to the NW and central parts of the basin, i.e. from the Novigrad Sea to the Krka River (Fig. 2), where tracing of the NCU is considered to be reliable. Farther to the SE, the previously proposed correlation (BABIĆ \& Zupanič, 2012) includes lacustrine deposits, and should be studied in the future.
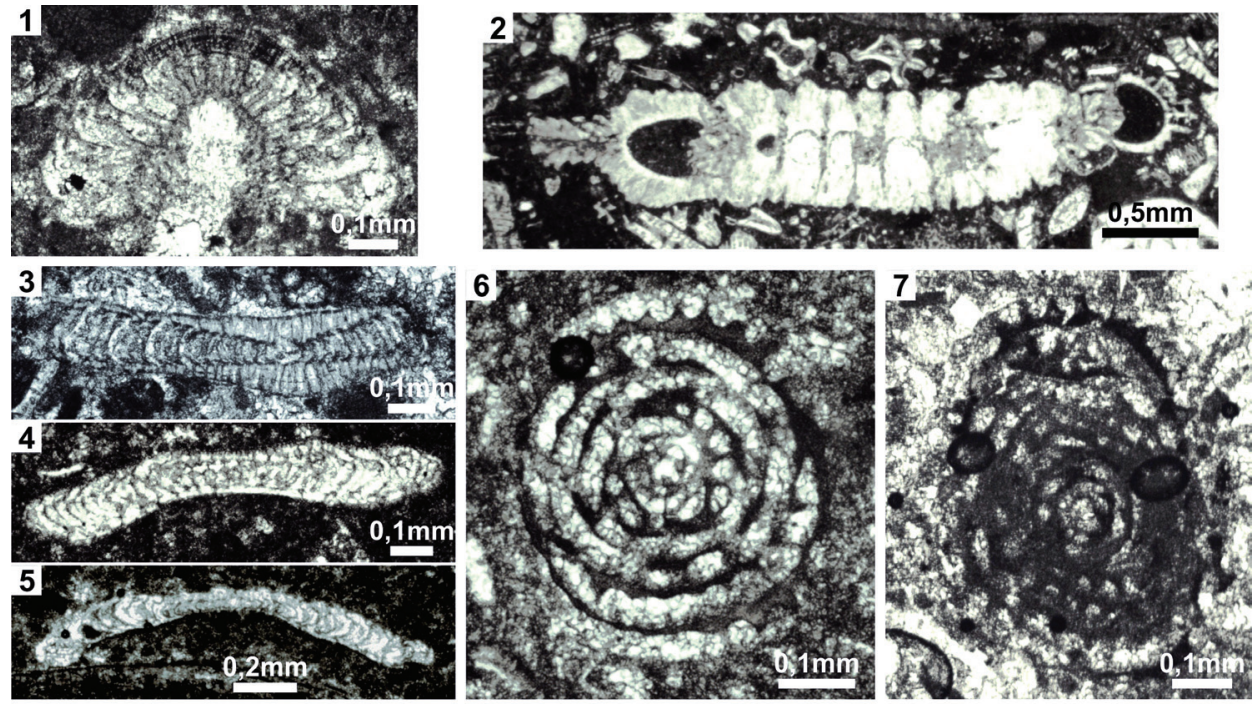
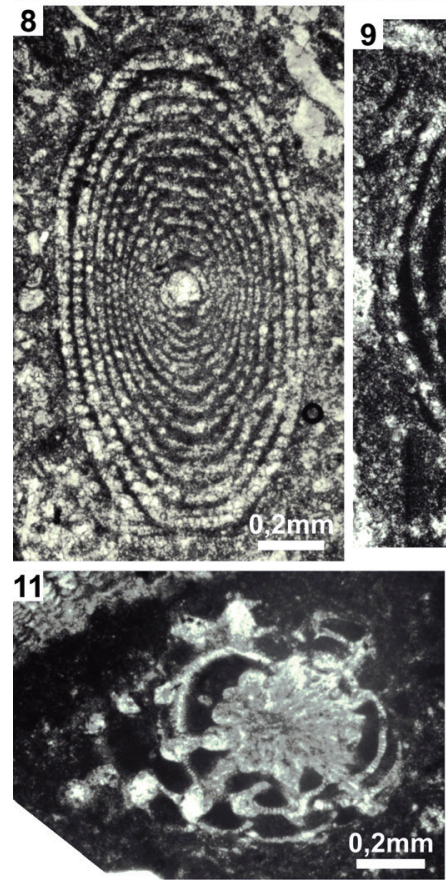
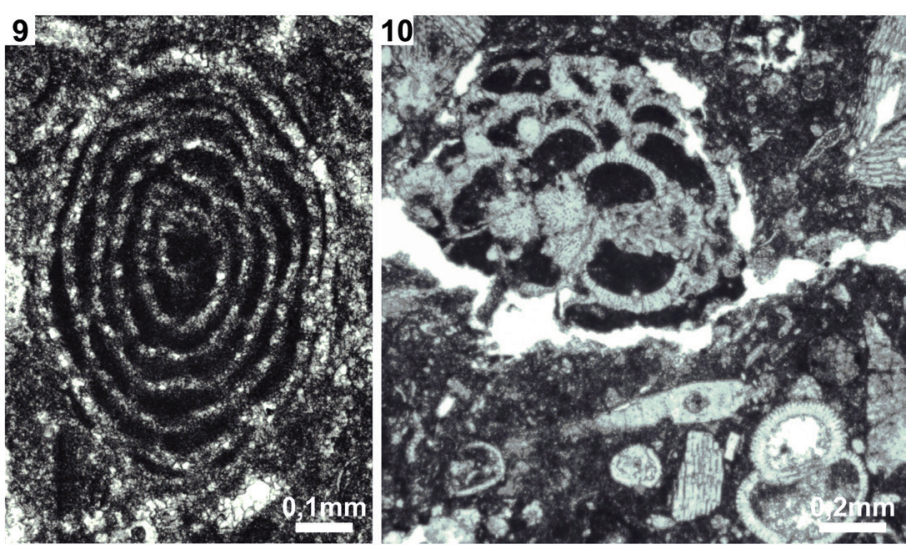
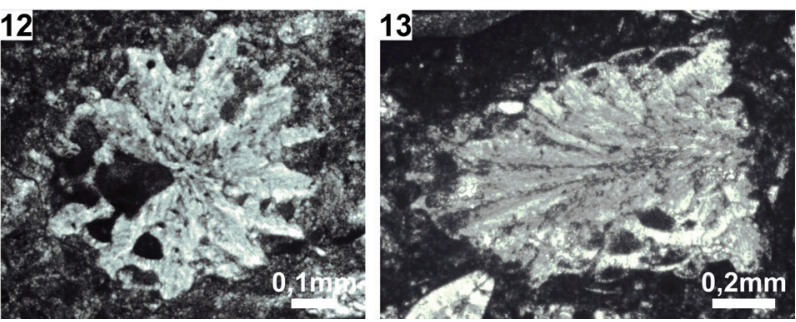
It is to be mentioned that the NCU also contains carbonate platform limestones in several horizons (Fig. 5), which originated during transgressive intervals. However, they reflect new, fundamentally different conditions compared to the succession of previous carbonates including their topmost portion represented by the UNL. The new conditions during the deposition of the NCU include an intermittent supply of terrigenous detritus derived from the orogen which resulted in the alternation of clastics and carbonates.

\section{CONCLUSION}

The Upper Nummulitic Limestones of Schubert $(1908,1909)$ situated in the NW part ofthe North Dalmatian foreland basin reflect the deposition on a land-attached ramp belonging to atemperate sediment province. The deposition of these limestones began in very shallow, restricted settings which subsequently evolved into a well-aerated carbonate platform with diversified biota. The relevant sedimentary succession terminated at a drowning unconformity. The Upper Nummulitic Limestones are either Late Lutetian and Bartonian or possibly, entirely Bartonianin age, while the drowning unconformity is an intra-Bartonian bounding surface. It has been demonstrated that the Palaeocene-Middle Lutetian Foraminiferal Limestones do not represent the last platform carbonates in the evolution of the Dinaric carbonate platform, and the platform was still alive in the Bartonian although reduced in size. The studied limestones represent the youngest, hitherto unknown stage in the Dinaric platform development and a component of the evolution of the Outer Dinarides. The succession of Upper Nummulitic Limestones represented the platform component of the reconstructed platform-basin system which constituted an important part of the Dinaric foreland. The basin received

$\Leftarrow$

Plate II. Selected foraminifera from the middle-upper part of the Upper Nummulitic Limestones. 1, Halkyardia minima.2, Biplanispira. 3, Linderina. 4 and 5, Eoannularia eocenica. 6 and 7, Borelis vonderschmitti. 8 and 9, Glomalveolina ungaroi. 10-13, Silvestriella tetraedra. In 10, lower left there is also a planktonic foraminifer. 1, 3-5, 7 from section 3; 2 from section 7; 6, 8, 9 from section 4; 10 from section 5; 11 and 13 from section 8. Section location in Figs. 3 and 4.
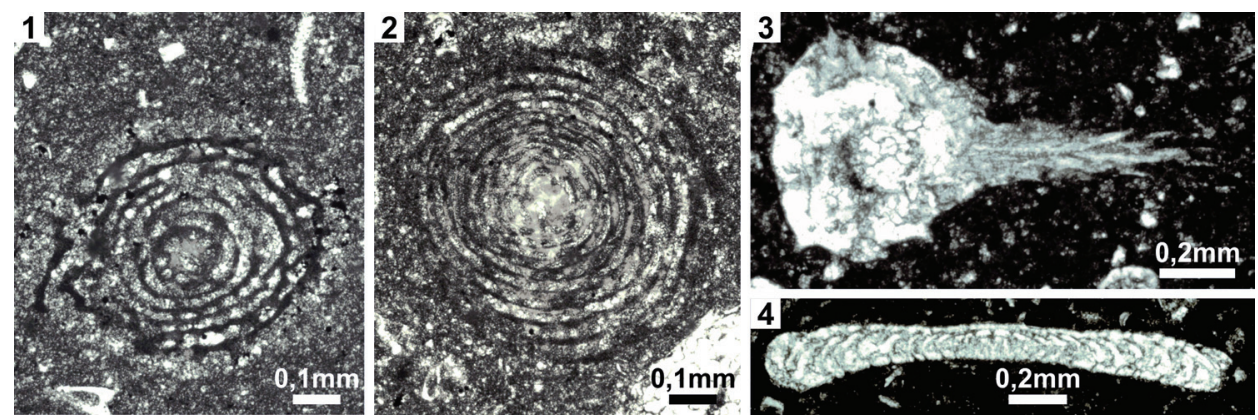

Plate III. Selected foraminifera from the Novigrad Cyclic Unit. 1, Borelis vonderschmitti. 2, Glomalveolina ungaroi. 3, Silvestriella tetraedra. 4, Eoannularia eocenica. Location in Fig. 5. 
lithoclasts including huge limestone blocks from the faulted, collapsing margin of the platform, including skeletal particles from its surface. The process resulted in megabreccias deposited in the adjacent basin of the Lower Promina Beds.

\section{ACKNOWLEDGEMENTS}

We thank Professor B. Glumac (Smith College, Northampton, USA) and Dr. B. LužarOberiter (Faculty of Science, University of Zagreb) for valuable comments which considerably improved the manuscript. Mr. D. Vončina and Mr. Ž. Ištuk are thanked for the preparation of thin-sections, and Mr. R. Košćal for the artwork (all of them from the Department of Geology, Faculty of Science, University of Zagreb).

Received April 25, 2016

\section{REFERENCES}

Aubouin, J., Blanchet, R., Cadet, J.P., Celet, P., Charvet, J., Chorowicz, J., Cousin, M. \& Rampnoux, J.P., 1970: Essai sur la géologie des Dinarides. Bull. Soc. géol. Fr., 12/6, 1060-1095.

Babić, LJ. \& Zupanič, J., 1983: Paleogene clastic formations in northern Dalmatia. In: BABIć, LJ. \& JELASKA, V. (Eds.): Contributions to Sedimentology of Some Carbonate and Clastic Units of the Coastal Dinarides. 4th IAS Regional Meeting, Split, Excursion Guide-book, 37-61.

BABić, LJ. \& Zupanič, J., 2008: Evolution of a river-fed foreland basin fill: the North Dalmatian flysch revisited (Eocene, Outer Dinarides). Natura Croat., 17, 357-374.

Babić, LJ. \& Zupanič, J., 2012: Laterally variable development of a basin-wide transgressive unit of the North Dalmatian foreland basin (Eocene, Dinarides, Croatia). Geol. Croat., 65/1, 1-27.

Babić, LJ., Zupanič, J. \& LužAr-Oberiter, B., 2010: Evolution of a Dinaric foreland basin fill: flysch and molasse of North Dalmatia. In: Horvat, M. (Ed.): Excursion Guide-book, 4th Croatian Geol. Congr., Šibenik, 2010, 179-201.

Bassi, D. \& Loriga Broglio, C., 1999: Alveolinids at the middle-upper Eocene boundary in northeastern Italy (Veneto, Colli Berici, Vicenza). J. Foram. Res., 29/3, 222-235.

Benić, J., 1975: Paleogenski nanofosili Hrvatskog primorja (od Istre do Ravnih Kotara). MSc. Thesis, University of Zagreb, 82 pp. Zagreb.

Bignot, G., 1975: La transgression éocène et les terrains liburniens en Dalmatie septentrionale (Yougoslavie). Rev. Micropal., 18/1, 15-22.

Blair, T.C. \& Bilodeau, W.L., 1988: Development of tectonic cyclothems in rift, pull-apart, and foreland basins: Sedimentary response to episodic tectonism. Geology, 16, 517-520.

Boudagher-FAdel, M.K., 2008: Evolution and Geological Significance of Larger Benthic Foraminifera. Developments in Palaeontology and Stratigraphy, 21, Elsevier, 540 pp, Amsterdam.

Burns, B.A., Heller, P.L., Marzo, M. \& Paola, C., 1997: Fluvial response in a sequence stratigraphic framework: Example from the Montserrat fan delta, Spain. J. Sed. Res., 67/2, 311-321.

Dragičević, I. \& Velić, I., 2002: The northeastern margin of the Adriatic Carbonate Platform. Geol. Croat., 55/2, 185-232.

Drobne, K., Vlahović, I., Trutin, M., Pavlovec, R., Ćosović, V., Babac, D., Cimerman, F., Lučić, D. \& Pavšić, J., 1991: Excursion B - Ravni Kotari, Paleogene. In: Vlahović, I. \& Velić, I. (Eds.): Some Aspects of the Shallow-water Sedimentation on the Adriatic Carbonate Platform (Permian to Eocene). 2. Intern. Symp. on Adriatic Carbonate Platform. Zadar, Croatia 1991, Excursion Guide-book, 53-90.

Ivanović, A., SAKač, K., SoKač, B., Vrsalović-Carević, I. \& Zupanič, J., 1976: Basic Geological Map of Yugoslavia, 1:100.000, Geology of the Obrovac Sheet (in Croat., Engl. summary). Geološki zavod, Zagreb, Savezni geološki zavod, Beograd, $61 \mathrm{pp}$.

Ivanović, A., Sakač, K., Marković, S., Sokač, B., SOKAČ, B., Šušnjar, M., Nikler, L. \& ŠuŠNJara, A., 1973: Basic Geological Map of Yugoslavia, 1:100.000, Obrovac Sheet. Geološki zavod, Zagreb, Savezni geološki zavod, Beograd.

James, N.P., 1997: The cool-water depositional realm. In: James, N.P. \& Clarke, J.A.D. (Eds.): Cool-water Carbonates. SEMP Spec. Publ., 56, 1-20. Tulsa.

Korbar, T., 2009: Orogenic evolution of the External Dinarides in the NE Adriatic region: a model constrained by tectonostratigraphy of Upper Cretaceous to Paleogene carbonates. Earth-Sci. Reviews, 96/4, 296-312. 
KRAŠEninnikov, V.A., 1965: Stratigrafija paleogenovih otloženii Sirii. Trudi Geol. Inst. An. SSSR, 133.

KrašEninnikov, V.A., Muldini-MamužIć, S. \& Džodžo-Tomić, R., 1968: Signification des foraminifères planctoniques pour la division de Paléogene de la Yougoslavie et comparaison avec les autres regions examinées (in Croat., French summary). Geol. vjesnik, 21, 117-145.

Majcen, Ž. \& Korolija, B., 1973: Basic Geological Map of Yugoslavia, 1:100.000, Geology of Zadar Sheet (in Croat., Engl. summary). Geološki zavod, Zagreb, Savezni geološki zavod, Beograd, 44 pp.

Mrinjek, E., Nemec, W., Pencinger, V., Mikša, G., Vlahović, I., Ćosović, V., Velić, I, Bergant, S. \& MaTIČEC, D., 2012: The Eocene-Oligocene Promina Beds of the Dinaric foreland basin in northern Dalmatia. In: Vlahović, I. et al. (Eds.): Marine to Continental Depositional Systems of Outer Dinarides Foreland and Intra-montane Basins (Eocene-Miocene, Croatia and Bosnia and Herzegovina). 29th IAS Meeting of Sedimentology. Field Trip Guide, Topic Two: Promina Beds. Schladming, Austria, 2012. J. Alpine Geol., 54, 413-455, Wien.

MuLDINI-MAMUŽIĆ, S., 1972: Biostratigrafija paleogenskih naslaga šireg područja Zadra (Biostratigraphy of Paleogene beds in the broader Zadar area). Nafta, 22/4-5, 262-269, Zagreb.

Nelson, C.S., 1988: An introductory perspective on non-tropical shelf carbonates. Sed. Geol., 60, 3-12.

ÖZkan, E., Lees, G., OKaY, A.I., BÁldi-BeKe, M., KollÁnyt, K. \& Yilmaz, Ö., 2009: Stratigraphy and larger foraminifera of the Eocene shallow-marine and olistrostomal units of the southern part of the Thrace Basin, NW Turkey. Turkish J. Earth Sci., 19, 27-77.

Pencinger, V., 2012: Sedimentological and stratigraphical characteristics of the Promina Beds in the northwestern Dalmatia. Doctoral Thesis, Faculty of Mining, Geology and Petroleum Engineering, University of Zagreb, $195 \mathrm{pp}$.

Prelogović, E., Pribičević, B., Ivković, Ž., Dragičević, I., Buljan, R. \& Tomljenović, B., 2003: Recent structural fabric of the Dinarides and tectonically active zones important for petroleum-geological exploration in Croatia. Nafta, 55/4, 155-161.

SAKAČ, K., 1961: Geološka građa i boksitne pojave područja Novigrad-Obrovac u sjevernoj Dalmaciji. (Kurze Übersicht der geologischen Struktur und der Bauxitvorkommen des Gebietes NovigradObrovac in Dalmatien. (In Croatian, German summary). Geol. vjesnik, 14, 323-345.

SAVEZni GEOLošKi ZAVOd (Federal Geological Institute), 1970: Geološka karta SFR Jugoslavije, 1:500.000. Beograd.

SCHLAGER, W., 1991: Depositional bias and environmental change - important factors in sequence stratigraphy. Sed. Geol., 70, 109-130.

SChlager, W., 1989: Drowning unconformities on carbonate platforms. In: Crevello, P.D., Wilson, J.L., SARG, J.F. \& READ, J.F., (Eds.): Controls on Carbonate Platform and Basin Development. SEPM Spec. Publ. 44, 15-25. Tulsa.

SchuberT, R.J., 1904: Das Verbreitungsgebiet der Prominaschichten im Kartenblatte Novigrad-Benkovac (Norddalmatien). Jahrb. geol. Reichsanst., Wien, 54, 461-510.

Schubert, R.J., 1905: Zur Stratigraphie des istrisch-norddalmatischen Mitteleocans. Jahrb. geol. Reichsanst., Wien, 55/1, 153-188.

SchuberT, R.J., 1908: Geologische Spezialkarte der Osterreichisch-Ungarischen Monarchie, 1:75.000. Novegradi-Benkovac. Geol. Reichsanst., Wien.

Schubert, R.J., 1909: Erläuterungen zur Geologischen Karte der Österr.-ungar. Monarchie NovigradBenkovac. Geol. Reichsanstalt, Wien, 1-26.

SCHWeighauser, J., 1951: EinVorkommen von Neoalveolina aus dem vicentinischen Obereocaen. Eclogae geol. Helv., 44/2, 465-469.

Serra-Kiel, J., Hottinger, L., Caus, E., Drobne, K., Ferrández, C., Kumar Jauhri, A., Less, G., Pavlovec, R., Pignatti, J., Samsó, J.M., Schaub, H., Sirel, E., Strougo, A., Tambareau, Y., Tosquella, J. \& ZaKREVSKAYA, E., 1998: Larger foraminiferal biostratigraphy of the Tethyan Paleocene and Eocene. Bull. Soc. géol. France, 169/2, 281-299.

SinCLAIR, H.D., 1997: Tectonostratigraphic model for underfilled foreland basins: an Alpine perspective. Geol. Soc. Am. Bull., 109, 324-346.

Toumarkine, M. \& Luterbacher, H., 1985: Paleocene and Eocene planktic foraminifera. In: Bolli, H.M., Saunders, J.B. \& Perch-Nielsen, K. (Eds.): Plankton Stratigraphy. Cambridge Univ. Press, 87-154.

Vlahović, I., TišlJar, J., Velić, I. \& Matičec, D., 2005: Evolution of the Adriatic Carbonate Platform: Palaeogeography, main events and depositional dynamics. Palaeogeogr., Palaeoclimatol., Palaeoecol., 220/3, 333-360.

Zupanič, J. \& BABić, LJ., 1980/1981: The origin of the lower part of Promina Formation (Paleogene) northwest of Benkovac (Dalmatia) (in Croat., Engl. summary). Vesnik A-Geologija, 38/39, 227-230, Beograd.

ZuPANIČ, J. \& BABIĆ, LJ., 2011: Sedimentary evolution of an inner foreland basin margin: Palaeogene Promina Beds of the type area, Mt. Promina (Dinarides, Croatia). Geol. Croatica, 64/2,101-119. 